Spring 4-1-2004

\title{
Shaping a Body of One's Own: Rebecca Harding Davis's Life in the Iron Mills and Waiting for the Verdict
}

Adam Sonstegard

Cleveland State University, a.sonstegard@csuohio.edu

Follow this and additional works at: https://engagedscholarship.csuohio.edu/cleng_facpub

Part of the Literature in English, North America Commons

How does access to this work benefit you? Let us know!

Publisher's Statement

First appeared in Arizona Quarterly 60.1 (2014); revised version printed by permission of the

Regents of The University of Arizona

\section{Recommended Citation}

Sonstegard, Adam, "Shaping a Body of One's Own: Rebecca Harding Davis's Life in the Iron Mills and Waiting for the Verdict" (2004). English Faculty Publications. 19.

https://engagedscholarship.csuohio.edu/cleng_facpub/19

This Article is brought to you for free and open access by the English Department at EngagedScholarship@CSU. It has been accepted for inclusion in English Faculty Publications by an authorized administrator of EngagedScholarship@CSU. For more information, please contact library.es@csuohio.edu. 


\section{Shaping a Body of One's Own: Rebecca Harding Davis's Life in the Iron-Mills and Waiting for the Verdict}

This is what I want you to do. I want you to hide your disgust, take no heed of your clean clothes, and come right down with me,--here, into the thickest of the fog and mud and foul effluvia. I want you to hear this story. There is a secret down here, in this nightmare fog, that has lain dumb for centuries: I want to make it a real thing to you.

Rebecca Harding Davis, Life in the Iron-Mills

W ITH ominous lines like these, Rebecca Harding Davis opened her short novel Life in the Iron Mills ( 1861 ), asked her readers to peer out of their genteel and sterile drawing rooms, and introduced the proletarian world of Hugh Wolfe. Published in James Fields's The Atlantic Monthly in April, r86I, her story garnered even Hawthorne's and Emerson's attention. Republished by Tillie Olsen in 1972, it attracted notice as a point of origin for social realism, a stunning depiction of class inequities, and a complex feminist text. ${ }^{1}$ A Cultural Edition of contextual documents and her recently republished, supplemented autobiography have enabled fresh approaches to her work. Seldom have "mud and foul effluvia" proven so inviting for so many readers.

Criticism of the literary achievement of the art of Rebecca Harding Davis, however, has sometimes elided the metaphorical possibilities of 
the art of Hugh Wolfe. Most sculptors of the period studied in Europe and created ideal, allegorical depictions; Davis's sculptor-character learns his craft during breaks from work and renders rough, workingclass forms. Monuments of the period glistened in alabaster marble imported from Italy; Hugh's work shows its own origins in molten pigiron from western Virginia. The novelist shapes her most famous story out of "fog and mud and foul effluvia," and that story revolves around a hero who literally digs into the mud to give shape to his creativity. Exhorting readers to get themselves dirty in attempting to understand a working-class environment, she depicts a hero who similarly struggles to make art out of the very grit and foulness of proletarian life. Readers encounter Davis's working-class figure shaping a body of his own, the sculpture in korl, and encounter the owners of the mill trying to shape Hugh into a body of their own, a mill-hand that selflessly serves the industry's needs. As he helps his sculpture, the korl woman, to emerge as more than a lump of pig-iron, Hugh himself tries to emerge as more than a faceless mill-hand. When Hugh finds himself unable to release his spirit, he desperately turns from shaping a woman's body in korl to cutting at his own body of flesh. Davis's sculptural metaphors dramatize her hero's attempts to shape himself amid social and industrial forces that in themselves shape working-class bodies according to their own designs.

The lesser known, less compact, but just as complex novel Waiting for the Verdict ( $\mathrm{I}_{867}$ ) revisits the motifs of Life in the Iron-Mills as it dramatizes interracial relationships, racist and classist systems of determining identity, and individuals' attempts to escape those systems. ${ }^{2}$ John Broderip, one of that novel's heroes, uses the surgeon's scalpel as Hugh Wolfe had used iron and tin to cut at the bodies that society marks as "foreign" or familiar, Anglo- or African American, until he, too, loses his power to shape individual bodies. With the sculptor's chisel and the surgeon's scalpel, Davis discovered a complex set of metaphors for an individual's power of self-conception in conflict with his or her existence in a racialized, gendered body at the mercy of society and industry. Davis in turn aligned herself with characters who struggle with the limitations of self-determination, but realized that many of her teaders wished to see themselves untouched by such external shaping forces. Whenever she finds her language colluding with industry, working to classify or confine these figures instead of encouraging their own self- 
conception, she attempts to let a sculptor's "work"-in iron-mills as well as in artfully carved bodies—speak for itself.

Davis's best-known fiction takes place on the regional borders that make for great differences in individual lives. Wheeling, the setting of Life in the Iron-Mills, sits on a narrow strip of Southern land between the free States of Ohio and Pennsylvania. Davis's autobiographical Bits of Gossip (I904) locates Wheeling on the national road between the North and South, on the paths of West-bound settlers, and at a multiethnic crossroads for European immigrants (Writing Cultural Autobiography 24-25). The seemingly remote outpost becomes a check-point on nearly every cultural journey that matters. Wheeling belonged to Virginia, but when the State seceded in I86I, the town provided the meeting hall for an assembly that reversed Virginia's decision. Wheeling and much of northern Virginia soon voted to leave the Secessionist State, and to rejoin the Union as New or West Virginia. "Nowhere in the country, probably," Davis writes, "was the antagonism between its sections more bitter than in these counties of Virginia which the North thus wrested from the South-'for keeps"' (I02). Wheeling had seen Virginia's "Rebel Cheat counties" express their loyalty for the Confederacy, and had seen slaves express disloyalty by escaping across the Ohio River. More than just any town in a Border State, Wheeling was a place to have a divided state of mind.

Rebecca Blaine Harding probably sensed this ambiguity more than many of her fellow Virginians. As a toddler in Alabama and later as a seminary student in western Pennsylvania, she had witnessed America's sectional conflict first-hand. She married L. Clarke Davis, an attorney from the North, and raised a family in Philadelphia while providing Boston editors with stories set in Kentucky and Virginia. She wrote for Boston's Atlantic Monthly so prolifically that, in the four years beginning with the April, I $86 x$, publication of the story of Hugh Wolfe, one-third of the magazine's numbers contained her work. The magazine's editor, James Fields, changed her title from "The Korl Woman" to the less specific Life in the Iron-Mills, and later insisted that she dispel the "gloom" of her second novel, Margret Howth. When Davis wrote to Fields about that novel's many revisions, she urged him, "Don't leave anything out 
of it in publishing it. Deformity is better than a scar, you know" (qtd in Harris 82). When the editors of The Galaxy demanded that she cut more than thirty pages from her later novel Waiting for the Verdict ( 1867 ), she mobilized the same metaphor, replying that the excision "mutilates" the story (qtd in Harris I 32). ${ }^{3}$ Davis wrote for both sides of a deeply divided country, packaged her observations to cross regional as well as demographic borders, and metaphorically depicted the results as bodily wounds. Later, when the combination of pregnancy and an illness deemed to be "nervous exhaustion" prompted a doctor to bar Davis from reading and writing, Sharon M. Harris and Janice Milner Lasseter conclude that her "ominous premarital fears about being silenced in her wifely role were being realized" (Writing Cultural Autobiography 5). Though Davis did not always share in the full measure of her contemporaries' or her characters' misfortunes, as a woman writer whose sense of uniqueness came into conflict with the demands of her doctors, editors, readers, and family members, Davis could relate to characters who felt shaped and even silenced by extrinsic forces.

Life in the Iron-Mills meditates at length on the limited means of self-formation open to individuals. In describing the Welsh mill-hands to Davis's readers, the narrator remarks, "You may pick the Welsh emigrants, Cornish miners, out of the throng passing the windows, any day. They are a trifle more filthy; their muscles are not so brawny; they stoop more. When they are drunk, they neither yell, nor shout, nor stagger, but skulk along like beaten hounds. A pure, unmixed blood, I fancy: shows itself in the slight angular bodies and sharply-cut facial lines" (42). While this kind of ethnographic classification most often accompanies accounts of African tribes, Davis, whose own maternal ancestry was Welsh and Irish, gives readers a stooping race of objectified Celts. Heavy labor and potent alcohol have shaped the Welshmen's muscles and forced them to "skulk along," but blood inheritance accounts for their bodies' well-defined angularity. The outside world forces the Welsh miners into stooping postures and "cuts" them into wretched shapes; alternatively, a Welsh heritage swells from within until their bodies manifest the supposed traits of the race. A seed germinates to form individual Welsh character, but an indifferent iron industry shapes the body to fit the mill's machinery.

A hunchbacked, leftover by-product of the cotton mills, Deb 
repeats this motif of internal and external shaping. Davis truncates this character's name to show the cotton industry cutting into her identity as it twists and harms her body itself. The narrator introduces Old Wolfe, "a pale, meek little man, with a white face and red, rabbit eyes," and then says that Deb differs only by degree; "Only her face was even more ghastly, her lips bluer, her eyes more watery. She wore a faded cotton gown and a slouching bonnet" (43). Deb's gender seems to make no essential difference in this passage. Work has taken its toll on both bodies, and Deb only differs from a man who belongs to her father's generation by appearing even more haggard. The only feature here that distinguishes her femininity is the cotton gown. "King Cotton" constructs its worker's femininity by granting her feminine attire.

If Deb cannot set herself apart from Old Wolfe, she cannot get near enough to his son Hugh. Exhausted from her labor, she nonetheless carries Hugh his dinner, though she knows the puddler is only as kind to her as he is to a rat. "She knew that. And it might be that very knowledge had given her face its apathy and vacancy more than her low, torpid life. One sees that dead, vacant look steal sometimes over the rarest, finest of women's faces. . . There was no warmth, no brilliancy, no summer for this woman; so the stupor and vacancy had time to gnaw into her face perpetually" $(46-47)$. The knowledge of her unrequited affections writes itself upon Deb's face, while the world as it passes by makes deep cuts in Deb's and the Welsh workers' bodies. The marks of disappointment in love steal across Deb's demeanor the same way they would cross "the rarest, finest women's faces," and class ranking seems to offer no protection against this slow erosion.

Deb has little chance in working at the spools to develop a unique selfhood, and thus Wai Chee Dimock is correct in interpreting her character as "less as an identity than as the impossibility of identity" (95). Davis's point does not seem to be that she wholly lacks identity, however, but that an identity imposed from the outside overshadows one that tries to emerge from the inside. The hands in the iron-mill ignore what Davis calls Deb's "groping passionate love" or "heroic unselfishness." "If anything like this" passion or heroism was "hidden beneath the pale, bleared eyes and dull, washed out face, no one had ever taken the trouble to read its faint signs" $(46)$. Anguish and unrequited love are emerging from within to shape her body and "gnaw" 
on her face. But industry is misshaping that body from the outside as it ignores these internal needs. Both an external shell for her emotions to "gnaw" upon, and a readable record of the cotton industry's abuse, Deb's body reflects the dual processes acting mercilessly upon it.

With her story's hero, Davis shows an artist who attempts to transmute the forces that ordinarily shape him according to physical needs, into his own means of shaping and creating. Outside forces dislodge Hugh from conventional demographic categories while he seeks to express his uniqueness:

Physically, nature had promised the man but little. He had already lost the strength and instinct vigor of a man, his muscles were thin, his nerves weak, his face (a meek, woman's face) haggard, yellow with consumption. In the mill he was known as one of the girl-men: "Molly Wolfe" was his sobriquet. He was never seen in the cockpit, did not own a terrier, drank but seldom; when he did, desperately. He fought sometimes, but was always thrashed, pommelled to a jelly. The man was game enough, when his blood was up: but he was no favorite in the mill; he had the taint of school-learning on him,- - not to a dangerous extent, only a quarter or so in the free-school in fact, but enough to ruin him as a good hand in a fight. $(47-48)$

An "instinct vigor" and pugnacious blood show an inheritance controlling an individual's temperament, but the mill's repeated skirmishes have simultaneously attenuated his body. Academic study has not strengthened Hugh mentally, but "ruined" him physically. Though it has introduced effeminate tendencies poorly suited to the mill environment, and supposedly made him less of a man, it has not made him something categorically different. ${ }^{4}$ As Hugh Wolfe experiences the gradual wearing down of his body, he becomes effeminate but not female. His work of art, the korl woman, is similarly worn down, becoming "feminine" but not female. External shaping obscures internal identity for the artist as well as the work of art, making Hugh, a man, appear to be a woman, and the korl woman, a thing, appear to be human. His aesthetic, which is influenced if not imposed from above, blurs the body's categories of male and female, of unique person and objectified or 
beastly "thing." Davis's name for her hero obfuscates these distinctions all the more. The given name of a grandfather, an uncle, and a brother in Davis's immediate family, "Hugh" could suggest the second-person pronoun, the word for shade or color, the verb for crudely cutting stone, or the emotion of a "hue and cry." The savage connotations of "Wolfe," however, negate his humanity. He derives his identity from an ontological conflict between a thing, a body shaped for the sake of labor, and a person, a spirit inclined toward shaping for the sake of art.

The narrator reads the minds of the rest of the laborers to determine why Hugh is "one of the hands" to some, a misunderstood outcast to others:

For other reasons, too, he was not popular. Not one of themselves, they felt that, though outwardly as filthy and ash-covered; silent, with foreign thoughts and longings breaking out through his quietness in innumerable curious ways: this one, for instance. In the neighboring furnace-buildings lay great heaps of the refuse from the ore after the pig-metal is run. Korl we call it here: a light, porous substance, of a delicate, waxen, flesh-colored tinge. Out of the blocks of this korl, Wolfe, in his off-hours from the furnace, had a habit of chipping and moulding fingers,-hideous, fantastic enough, but sometimes strangely beautiful. . . . (48)

Industry, as metaphorically represented in the pervasive dirt of the Wheeling setting, homogenizes working-class individuals as it transforms them into interchangeable sets of dirty "hands." White or black skin; Anglo, Irish, or Welsh bodies-Wheeling dyes them all the same gritty shade of gray. The environment and the industry impose a working-class, homogenizing identity from without as it obscures a unique, personal identity attempting to emerge from within. Hugh expresses himself with those ashes, and his expressiveness is his rebellious urge toward uniqueness. He takes the ash and soot that ordinarily coat him and mark him as an interchangeable member of the working class, and makes the dirt his own self-expressive medium. What ordinarily shapes and colors his body enables him to shape a body of his own. 
His dismal life in the working class gives him little encouragement to create idealized figures from gritty raw materials. The korl woman repeats the crude handling of her environment, and embodies the coarse nature of her "creator's" existence. "There was not one line of beauty or grace in it," readers learn of the sculpture, "a nude woman's form, muscular, grown coarse with labor, the powerful limbs instinct with some one poignant longing. One idea: there it was in the tense, rigid muscles, the clutching hands, the wild, eager face, like that of a starving wolf's" (53). In a return of the language of biological essentialism, both Wolfe's feminized body and the korl woman's humanized form are "instinct" with some primal need. As a wolfish laborer, Hugh joins the "beastly" Old Wolfe, with his "rabbit eyes," and the Welsh mill-hands, who "skulk" like "beaten hounds." The sculpture's lupine face similarly recalls both the artist's name and his objectification as a "beast." Davis's character and the body he shapes both seem stalled in intermediate stages between relatively stable categories of identity. His korl-woman is his self-expressive means of turning the soot that ordinarily coats him into a sculptor's pliable clay.

He ironically repeats these acts of shaping bodies at the story's close, when he desperately tries to cut at the shape of his own body in a jail cell. Deb takes Mitchell's wallet and Hugh briefly considers what he should do with the stolen money. Soon he must face Judge Day, and finds himself convicted and sentenced. The iron bars of his cell merely echo the iron ore of his previous confinement: he is scarcely less free as a prisoner in the cell than he had been as a laborer in the mill. A onetime worker in a Cornish tin-mine before coming to Wheeling's mills, he spends his final days sharpening a piece of tin against iron bars. Davis makes tin and iron, the metals that plague his life, play a role in his death. The iron industry's demands had always shaped Hugh, and now he uses those same tools, sharpened by the same ore, to "carve" himself and allow his spirit's escape. Davis's last glimpse of Hugh shows his spirit draining away:

Fainter and fainter the heart rose and fell, slower and slower the moon floated from behind a cloud, until when at last its full tide of white splendor swept over the cell, it seemed to wrap and fold into a deeper stillness the dead figure that never should move again. Silence deeper than the Night! Nothing 
that moved, save the black, nauseous stream of blood dripping slowly from the pallet to the floor! $(7 \mathrm{I})$

Even in death, Hugh exists in a world that determines identity by subjective and external means. The mill's grey soot had marked Hugh's body as working-class; now the moon can shed its light to make his corpse appear ashen and white. Once the moon sets, Hugh will presumably appear both dark and lifeless. When Hugh cuts himself, then, he allows his internal spirit to escape all of the earthly body's identities, to release that spirit as blood seeps away from the body itself. Even at the cost of self-sacrifice, this artist-character tragically reaches for a means of self-determination.

THE OBSERVER AND THE LANGUAGE

Davis tries to use the language of her story and the opinions of her narrator to encourage Hugh's emergence as a transcendent artist, and to resist the objectification that seems inherent in industrialism as well as in fictions of the working-class. In the conversation that Davis narrates between Mitchell, May, and Kirby as obtuse observers, and Hugh as an inarticulate artist, Davis asks how the working class and the relatively privileged can come to common understandings. These visitors to the mill use language to manipulate Hugh and to disclaim any tesponsibility for the kind of life he is obliged to lead. Davis in turn positions herself as far from Mitchell's and Kirby's linguistic elitism, and as near to Hugh's muddy, commonplace sincerity, as her language will allow. If bourgeois fictions about the working class serve to objectify laborers, Davis tries instead to encourage observers and laborers to find a common element-in the clay around them, if not in the language itself.

Kirby, for one, clearly belongs to the possessing class. As the son of the mill owner, Kirby takes a casual tour among the laborers who toil agonizingly for the Kirby family's livelihood. Even when he glimpses Hugh's statue of the korl woman, Mitchell argues against any claim that he is involved in the workers' lives. "Ce n'est pas mon affaire," he says, trusting the workers' well-being to Providence: 
"I tell you, there's something wrong that no talk of 'Liberte' or 'Egalite' will do away. If I had the making of men, these men who do the lowest part of the world's work would be machines,nothing more, hands. It would be kindness. God help them! What are taste, reason, to creatures who must live such lives as that?" He pointed to Deborah, sleeping on the ash-heap. "So many nerves to sting them to pain. What if God had put your brain, with all its agony of touch, into your fingers, and bid you work and strike with that?" (54)

Kirby exhibits a fascinating and inconsistent recognition of his own social responsibilities. His rhetoric collapses men's individual bodies into interchangeable hands that can labor. He does not say that the lowest class of workers would be replaced by machines, but that the lowest class would actually become the system's unfeeling cogs. While Kirby does not literally have the "making of men," his family has undoubtedly done much to shape Wolfe's life and occupation. Wishing men could be machines that cannot feel pain, Kirby may sound compassionate. But the workers' pain has paid for Kirby's pleasure.

He expands upon his own metaphor when he remarks, "I wash my hands of all social problems" (55). He likens workers to hands, and then alludes to hands again when he denies his involvement in their suffering. Kirby's knowledge of "Egalite" and "Liberte" and his allusions to Pontius Pilate's hands supposedly exonerate him for his erudition, but do not demonstrate a full comprehension of his own references. "My duty to my operatives," Kirby says, "has a narrow limit,- the pay-hour on Saturday night. Outside of that, if they cut korl, or cut each other's throats, (the more popular amusement of the two,) I am not responsible" (55). Kirby's family has benefitted from shaping men like Hugh to the industry's needs, but Kirby exempts himself from responsibility for shaping their lives. That Hugh will eventually cut his own throat exposes the irony: Kirby is more intimately involved in this worker's life and death than he can see from his privileged position.

Mitchell comes closer than Kirby to understanding Wolfe, but finally reacts to the korl woman in ways that echo Kirby's noncommittal stance. In Mitchell's interpretation, the statue "asks questions of God, and says, 'I have a right to know.' Good God, how hungry it is!" (54). Mitchell speaks of the statue's own hunger and seems closest to 
comprehending the narrator's ideas of instinctive longing. But he reads within it another erudite and self-exonerating theory:

Reform is born of need, not pity. No vital movement of the people's has worked down, for good or evil; fermented, instead, carried up the heaving, cloggy mass. Think back through history, and you will know it. What will this lowest deep-thieves, Magdalens, negroes—do with the light filtered through ponderous Church creeds, Baconian theories, Goethe schemes? Some day, out of their bitter need will be thrown up their own light-bringer,- - their Jean Paul, their Cromwell, their Messiah." (57-58)

Mitchell's dismissal of any social theory that works from the equestrian to proletarian class exempts him from social obligations, just as a similar idea had allowed Kirby to wash his hands of others' misfortunes. To this way of thinking, the working classes, who will eventually help themselves, cannot possibly benefit from philanthropic aid. Notice that Mitchell ignores Hugh's uniqueness, placing him in "this lowest deep," with "thieves, Madgalens, and negroes." He justifies his neglect of a guiltless, Welsh bachelor with a non sequitur, a claim that he cannot aid criminals, Africans, or prostitutes. Inattentive to differences of status and nationality, Mitchell excludes himself from an eclectic group of variously guilty parties. Wheeling's soot colors every worker a uniform, grey hue, and the town's patricians follow the environment's lead. Failing to discern any demographic distinctions among the oppressed mill-workers, they discriminate indiscriminately. They assume that what is true of this "Hugh" is true of them all.

If this attempted wordplay shows me struggling with language as I describe Davis's work, I am not alone in working with an unwieldy linguistic medium. Davis and her much-discussed narrator also struggle to use language in ways that are opposed Mitchell's and Kirby's manipulative elitism, and akin to Hugh's self-expression. ${ }^{5}$ While the visitors to the mill use language to shape the lives of the working class and to disown their own responsibilities to that class, Davis uses language to keep her narrator from becoming identifed, gendered or even embodied in any conventional sense. Rosemarie Garland Thomson has an 
excellent point in noticing that the narrator is "strikingly disembodied in comparison to the wretched mill workers, whose physical suffering is rendered in vivid detail" (57I). Indeed, in the story's framed narrative, to have a laboring body is to suffer for it: Deb has the body of a woman of the cotton industry, but she looks just as haggard as Hugh's elderly father; Hugh himself has the laboring body of a man, but appears attenuated from a supposedly effeminating education. The korl sculpture in turn has the body of a woman, but retains the status of a thing, an industrial byproduct. External shaping partially dislodges each working-class being from a stable ontological category. But in the story's framing device, the narrator escapes this arbitrary shaping of identity that comes of efforts to describe or categorize the body. If individuals get shaped and constructed by indifferent, external systems, Davis avoids this condition by leaving her narrator both unidentified and unembodied.

The story's convoluted opening shows this narrator's efforts to encourage Hugh's emergence and stymie the reader's impulse to objectify him as a member of the working class:

I want you to hear this story. There is a secret down here, in this nightmare fog, that has lain dumb for centuries: I want to make it a real thing for you. You, Egoist, or Pantheist, or Arminian, busy in making straight paths for your feet on the hills, do not see it clearly,-- this terrible question which men here have gone mad and died trying to answer. I dare not put this secret into words. I told you it was dumb. (4I)

The narrator cannot phrase the statue's question in words and cannot adequately represent an entire class of people with one night in Hugh Wolfe's life. Readers are thereby obliged to see themselves actively experiencing the narrator's story. Grouping Egoist and Pantheist theories with Mitchell's Kantian or Comtist philosophies, the narrator implies that all of these ways of thinking blind people to what they are supposed to see as "the real thing." The tone carries a class bias: a clearly differentiated "You" and "I" can elect to remain formally dressed, but an undifferentiated mass of proletarians must cope with "vile, slimy lives" (4I). Breathing the same air and digging into the same mud, however, 
at least means sharing the same world with the workers. The narrator's hesitant phrasing refuses to use language to distance the speaker or the reader from the working-class environs of the story.

"I can paint nothing of this," the narrator then says of a vaguely invoked "reality of soul-starvation," and can "only give you the outside outlines of a night, a crisis in the life of one man: whatever muddy depth of soul history lies beneath you can read according to the eyes God has given you" (47). This hesitant handling of the medium, shadowed by a more "muddy" medium, commonplace sculpture, dramatizes Davis's worries over maintaining a crucial distinction. Wishing to "only give you the outside outlines" of a working class life, the narrator does not want to give the defining outlines to such a life. The idea is to present a blue-collar existence "as it is," without externally shaping readers' perceptions of it, to show the "real" Hugh, and not to use language to shape him into something observers like Mitchell and Kirby can conveniently see and appropriate. At the story's close the narrator remarks that the korl woman shows "grand sweeps of outline that show a master's hand" (74). The story supplies the "outside outlines"; the artist embedded within the story sculpts "grand sweeps of outline." Davis mimics her sculptor in providing only rough contours, within which readers can infer distinct detail. She avoids cruelly shaping the lives of her characters in ways that would mimic industry's indifferent shaping.

By the end of the tale, however, the narrator does not seem to be acting in accordance with the story's class politics or ideals of self-conception. After advocating that readers dig into the mud, the narrator in the end appropriates the statue of the korl woman, itself made of hardened mud, for her home. The narrator, readers discover, lives in the house that the Wolfes had inhabited, and possesses Hugh's sculpture as exotic or "naive" art. The narrator may live among the working classes and relay their stories, but Davis's figure possesses the class's products without actually having to work alongside them. The narrator alone has the idle time to realize that the others spend too much time laboring.

The narrator's passivity and the repeated references to incompleteness, however, give readers cause to qualify this prevailing interpretation of the narrator as dilettante. There is "a half-moulded child's head" in the studio, and evidently the artist is unable to complete the work of 
representation. As to the story, "nothing remains to tell that the poor Welsh puddler once lived, but this figure of the mill-woman cut in korl" (74). This is odd, since for Davis's readers, the only record of Hugh is the narrative itself. Davis has the narrator temporally situate the conclusion of the tale by saying, "the deep of the night is passing while I write" (74). If readers "possess" anything in the full daylight of the next morning, it is the narrative and not the statue. The narrator denies that the written story has any power as a record of a working-class life, and claims that the statue alone remains to tell the tale. The mute statue relieves the narrator's anxiety and "does" more than words have been able to do. It remains behind to signify the story that the narrator will not trust words to convey. If language, akin to Kirby's and Mitchell's elitism, shapes and appropriates lives like Hugh's, then an alternative language, likened to commonplace sculpture instead, ensures that Hugh's art remains his own. The work of Davis's sculptor is understood to exceed even the descriptive, appropriative powers of his observers.

\section{THE SURGEON AND THE WOUNDED}

Like Deb and Old Wolfe, Davis's characters in the 1867 novel Waiting for the Verdict are shaped and formed by external forces. Like Hugh and the korl woman, they show a compulsion to push beyond the limitations imposed upon their bodies, and even a willingness to cut at the body's flesh to escape those limitations. Waiting for the Verdict asks searching and finally unanswered questions about the roles of nature and nurture in determining individual character, and about racial identities as minor differences in degree, or major differences in kind. Some of Davis's characters feel they differ from their fellows only to the extent that the world's shaping forces have inconsistently nurtured them or neglected them. Other characters find demographic boundaries impassable, and experience a "natural," visceral repugnance in the presence of other races. At times, then, the novel constructs racial difference as merely a matter of identical essences that are subjected to different degrees of external shaping; but other times, the novel's black and white bodies seem to be made from forever separate, wholly incompatible clay.

Two story lines in the novel's broad landscape parallel one another as they illustrate these competing understandings of nature and nurture. 
In one story, Rosslyn Burley and Garrick Randolph each hide a secret aspect of their identity that Davis treats as a latent essence behind a strategic mask. Born Rosslyn Comly but known by her adopted name of Ross Burley, Davis's young heroine feigns respectability to conceal her illegitimate birth and impoverished childhood. As a gamine she had worked as a common huckster in the public market place, and as a child she had emerged from some vague connection with a slave owning family named the Streblings. Ross's adopted father, Joe Burley, encourages her to act as a genteel lady, but she regards her childhood career as a huckster as sufficient reason to separate herself from privileged classes. Garrick Randolph represents, then, exactly the patrician demographic she avoids. The former Miss Comly's comely appearance, her seemingly aristocratic bearing, nonetheless attracts him and deludes him into thinking Ross embodies upper-class refinement.

For his part, Garrick carries Southern racism to a repugnant extreme as he enjoys the perquisites of his Dixie heritage. Somewhere in the distant past, however, a Randolph forebear cheated his fellows to preserve the family fortune. An episode vaguely involving a will, a slave servant who witnesses the will but who cannot testify legally (Kentucky legal code refusing to recognize African American testimony), and the same Strebling clan that also haunts Ross's past, all complicate Randolph family fortunes. The narrative says of Ross's childhood poverty that "vulgar training is the damned spot that will not out, whether you put its possessor in the White House or the Tuileries" (83), but remarks that Garrick Randolph "cherished his pure descent back to the Champernouns of Elizabeth's time, a lineage on which there had fallen no stain of dishonor" (38). The "stain" on Ross's family record becomes indelible for posterity, while the Randolphs forever cherish and protect their supposed purity. Ross bears the marks of her low birth despite her efforts to rise socially. Randolph's family schemes to retain its riches, all the while considering itself pure.

The novel's other pair of lovers, Margaret Conrad and John Broderip, reverse this familiar pattern. Margaret is associated with Garrick Randolph in her family connections, but seems to have no dark secret in her family past to complicate her current identity as a privileged Southern woman. Unapologetically racist, she decries interracial relationships and cruelly caricatures overzealous abolitionists. 
She begins to fall in love with John Broderip, a respected if misunderstood surgeon and prominent citizen of Philadelphia. But Broderip, it turns out, has a sufficient number of drops of African American blood circulating in his body to qualify as black and to risk losing his medical practice if his "true" identity should come to light. Davis only vaguely indicates the details of Broderip's background, but it again involves the Streblings, spectral agents of every principal character's destruction. ${ }^{6}$

Ross's "vulgar spot" of poverty and low birth means that her marriage to Garrick Randolph would "adulterate" the Southern family with the intruding influence of a lower class. The sparse drops of African American blood in Broderip's body suggest a similar impurity in his proposed marriage with Margaret Conrad. In both cases, those with "tainted" backgrounds, lowly statuses, and earthy natures that recall Hugh Wolfe meet ostensibly pure individuals, who cannot in turn countenance another's impurity. Each union would involve one spouse, who harbors the supposed blemish of low birth or African-American ancestry, marrying an "untainted" spouse, who thereby would adulterate a previously unalloyed strain. Is it "pure," Davis asks, to protect a family from supposedly tainted blood? Or is it pure, in the sense of Christian magnanimity, to overlook such imperfections in others? Should individuals be forgiven for what are thought to be the sins of the fatherssins that blood supposedly passes on to their children?

Both stories meditate on such questions while using sculpture to govern the ambivalence between ideologies of nature and nurture. Garrick Randolph embodies his Dixie lineage as Davis makes him the Kentucky patriciate's monument to chivalry and manliness. The surgeon John Broderip at one point "glance[s] over at" the patrician Randolph's "sinewy figure and abstracted face, on which was the chiselling of generations of ease and culture" (123). He wears his Southern pride not only on his sleeve, but in his masculine frame and bearing. But when Margaret Conrad observes Randolph at a tense moment, she senses that such chisels might still be at work. She "would have said the shell was only breaking off which had crusted over him in the old college library, from which he had been dragged, and that a few more touches of the knife would bring all that was in him of good or ill to the light" (48). Randolph's "true" character emerges from within, even as a surgeon's knife shapes the mask from without. "The knife cut rough and deep," Davis's narration continues; "if some traits and lines which 
only God had seen before, yawned sudden and black on the surface, it only proved that the chivalric gentleman bore subtle kinship to us all beneath all difference of blood or color" $(48)$. Inner blemishes flare on the otherwise flawless surface of a monument to Dixie manhood. Southern culture merely shapes what to Davis is essential and uniform across demographic lines, a "subtle kinship" within the body itself.

Randolph meanwhile knows his statuesque ideal of womanhood. He pictures "an olive-skinned, fragile woman, with coils of black hair, and a Greek nose" as he envisions the womanly frailty and Mediterranean cast of neoclassical figures (86). When Davis describes Ross, whom Randolph pursues and who supposedly carries the supposed taint of her illegitimate birth, Davis's metaphors fall far short of an exotic Grecian setting, and instead recall Hugh Wolfe's industrial world. Determined to endure Randolph's callous prejudice, "Ross had a temper a good deal like molten steel-clear and liquid as water until it found its mould, and afterward, never to be bent or broken" (144). In one scene with Ross and Randolph, she "sat cold and motionless, her hands folded on her knees, her aquiline profile cut clearly between him and the gray window light" ( 145 ). Her distinguished and statuesque "cut" soon atrophies to that of a lesser stone: "For the first time he saw that" Ross's face "had curiously hard lines in it, that the very brown eyes which had seemed to him to be the softest, tenderest in the world, to hold all a wife's and mother's passion and pain latent in them, had a flinty look of dull endurance, which was new to him" (I45). Fancying himself shaped by privilege, Randolph searches Ross's lineaments for similar signs of a sculptor's touch. Instead he glimpses the steel and flint that signify her working-class origins.

When Randolph proposes marriage, he brings a miniature photograph of his mother to show Ross his distinguished lineage. Refusing to look at it, Ross places it face-down on a mantel-shelf, and explains, "I am not a woman in whose hands you would wish to place that picture. They are not clean according to your rules: there is not a drop of blood in my veins which would not be tainted-in your judgment"' (229). Refusing to take his hand in marriage, she will not even hold his mother's picture in her own unclean hands. Ross invokes the rhetoric of national ideal as she makes her meaning clear: 
"There is a fable that all men are born free and equal in this country," she said, with a sudden cool self-control. "It only needs for you and me to stand face to face to prove the baseness of the falsehood. Every man carried the stamp of his birth and breeding as plainly in his soul as on his face: but none plainer than you and I. I have heard of equality and brotherhood all my life, but there is not a face I meet on the streets which does not bear terrible marks of the difference made in the nature of a man by money and rank and the want of them. Sometimes my cast has the advantage, sometimes yours: but the gulf is always there." (229)

Davis's narrator had voiced ideals about shared kinship beneath the superficial masks of race and class, but Davis has her character declare that demographic distinctions cut to a depth well within the body, and well beneath any such mask. Distinctions of "cast" sometimes reflect only the world's loving nurture or malicious neglect of individuals, but sometimes speak to supposedly essential differences. Ross would stand to gain materially from denying her supposedly tainted origins, but she resigns herself to a rigid understanding of demographics, respecting an interpersonal boundary she sees as an unbridgeable "gulf."

Randolph, meanwhile, attempts to ovetcome his prejudices, but demonstrates just how deeply those prejudices run. Though Ross reminds him that her "childhood was passed in the lowest haunts of poverty; where stains cling to the soul, which, you were careful to tell me, never will wash away" (230), he swears he can marry her. Pontius Pilate's washing of hands, which Kirby had invoked in Life in the IronMills, returns at this crucial moment. Her confessions about her past seem briefly to Randolph make her a pure and beautiful woman, "but nothing more. There was neither name nor lineage nor kinfolk to marry with his wife" $(232)$. Just as he realizes that she represents no great family of her own, she looks at the object that represents his lineage, his mother's photographic miniature. She evidently does not like what she sees, "for love is in no haste to blind us to faulty facial lines in the countenance of our lover's mother" (232). She finds fault with a photographic image and acts as if inward traits, a combination of supposed sensuality and indolence she sees in Mrs. Randolph, appear written on the matriarch's face. 
The Randolph family scion is understandably aghast at Ross's attitude toward his mother's image. "It did not seem. fitting to him that James Strebling's illegitimate daughter," as Ross has revealed herself to be, "should look with critical eyes at his dead mother's face. But Ross, he saw, with a curious irritation, had apparently forgotten who and what she was" $(232-33)$. Her "place" seems set beneath that of the woman in the photograph, and her suitor takes umbrage when she acts otherwise. While Randolph seems willing to forgive Ross's supposedly benighted and impoverished past, he cannot excuse her disrespect toward his own refined lineage. For Randolph, Ross's behavior is not merely an accident of high or low birth, but a supposed inferior's obligation to defer to someone formed from finer clay.

John Broderip and Margaret Conrad make these sculptural motifs overt in terms of actively shaping, cutting, and even amputating bodies, not with a sculptor's chisel, but with a surgeon's knife. When Margaret appears in a particularly majestic pose, Broderip sees that "the heavy dress of ruddy hue showed the full contour of her head and bare throat, solid and pale as yellowish marble, with the black coils of hair falling loosely down" (198). Even in anger, the Southern woman shows her statuesque poise when Broderip notes that her "beautiful face was carved between him and the fading light, set and stern" (201). But Broderip, the mulatto surgeon passing for white and operating a successful practice in Philadelphia, seems a latter incarnation of Hugh Wolfe in his jail cell, and not a trained sculptor. When he is intrigued by Margaret's beauty, Broderip's "pale, insignificant face" "grew, slowly, fine-nerved and wistful as a woman's, the protruding forehead lowered, a rare, subtle intellect looked out of the hazel eyes, which were usually but a shining, confusing mask; the mouth moved, irritable and tender" (74). Delicate in form and feminine in feature, Broderip repeats Hugh Wolfe's incongruous femininity as well as Davis's motif of the mask reflecting the shaping of internal as well as external forces. When two minor characters, Farr and Hubbard, bring a patient in for Broderip to dress his wounds, Farr knows that "there was relish, an actual gusto, in his small colorless face as he cut tonight into this man's flesh; even George Farr's partial eyes saw that. He hacked it cruelly, as if it were his enemy that lay before him, his lips tight shut, his eyes in a blaze. Even Hubbard, who was a big bully of a fellow, pulled at his moustache, 
losing color, growing more subservient to Broderip every moment" (I09). Hugh Wolfe had slashed at his own body as identifying strains of color and blood had drained away. With Broderip's observers becoming flush or "losing color," this surgeon also cuts at flesh that determines individual, racial identity.

The surgeon's cutting becomes a startling personal epiphany for Broderip later in the novel, when Randolph has Broderip dress the wounds the elderly slave Joe Burley. Broderip makes surgical incisions into Burley's flesh while Randolph casually mentions one of his family's old slaves. Broderip asks for the old slave's name and Randolph answers, "The negro's name is Hugh." Davis immediately makes the patient groan in distress and urge Broderip, "'Have a keer, Doctor! have a keer!"' "Intent on his conversation with Randolph," the surgeon, Davis tells us, "had wrenched the wound half open with a sudden turn. He bent close over it now, concealing his face as he repaired the injury, gnawing his under lip as a man does who is angry with himself" (239). The cut to the body's wounds, the name "Hugh," and the tooth that once again gnaws in remorse at the body, echo Life in the Iron-Mills as they show another Davis hero coping with the uneasy conjunction of corporeality and identity. Hugh, the old Randolph-family slave, is in fact Dr. Broderip's father. He works as a surgeon, then, for the Southern family that warped his own family's lives. He cuts at the request of Garrick Randolph, whose clan has cruelly shaped Broderip's own existence. Concealing his African-American family heritage as he cuts into the body itself, Broderip unconsciously lets his knife slip when he hears someone say, "the negro's name is Hugh."

"The negro's name is Hugh." The "negro" is-you. No one thus reveals the status of the racially passing surgeon, and yet the possibility of such a revelation becomes his fixation. Acknowledging his heritage would mean losing his practice, alienating Margaret, and perhaps placing himself at a lynch mob's mercy. Refusing to acknowledge it means feeling his drops of black blood start to sting every time someone expresses revulsion for blacks, and quaking every time he hears someone say "Hugh." He lives for decades without discovering the fate of his African American father, who bears that very name. He visits Philadelphia's slums and feels disgusted by destitute blacks' lives. As others watch him at work in his operating room, however, he treats a wounded African American girl and kisses her affectionately, thereby 
breaching racial as well as professional etiquette. He separates himself from African Americans and ordinarily practices medicine exclusively on whites, and yet he still feels the sting of his black drops of blood each time Margaret, his statuesque white love, expresses disdain for black flesh.

Davis forces the moment to its crisis when she brings Nathan, Broderip's long-lost brother and Hugh's other son, to Broderip's operating room. Nathan is visibly darker in skin tone, and when Broderip recognizes him, he knows what it would mean to acknowledge his brother. He would be "a negro-no wealth, no talent, no virtue could wash out that stain or put him on a level with the meanest servant in his house again" (300). The stain would be indelible, but the flesh potentially could yield: he regards his scalpel and realizes, "One touch of its blade, and his secret was safe forever. He stretched out his hand for it" (30I). A character shaped by outside forces and blood inheritance stands to shape and even mutilate the body that bears the marks of that external shaping. Hugh Wolfe had slashed at his own flesh and caused his blood, already fixed in terms of race and class, to flow free from the body. Now John Broderip seems about to slash at his brother's body to free himself from having to recognize the blood that cruelly fixes his own status. If he cuts at his brother's body, he would feel it as a cut to his own heart, but he would be able to marry Margaret Conrad, whose face seems cut of the finest marble to show the womanly ideal. Once again a Davis character seems poised to turn the body, which cruelly shapes his life and identity, into his own material for shaping his life and family.

Davis has Broderip relent, bring Margaret in to see his brother on the operating table, and admit to his kinship. Broderip observes Margaret and notices how "the folds of her dress and heavy shawl were still as if she had been a statue," and Margaret, whose "eyes were dull, her face stony" replies that "the gulf between us is one that God never intended to be crossed" (309-ro). "Stony" and statuesque, she explains that her disgust for the black body must finally prevent them from becoming man and wife. Though Davis's narration had at times suggested that race is merely a matter of the world's inconsistent nurturing of individuals, Margaret, like Ross Burley, sees the supposed line between races as an unbridgeable "gulf." Margaret would stand to lose caste and endanger her supposed purity if she bridged the rift between racial groups, 
while Ross would gain materially from doing so. Both women, then, reinforce a demographic border when they have a chance to breach it. In Sharon M. Harris's phrasing, Davis “presents Margaret's ingrained prejudice as tragic precisely because the young woman cannot overcome her biases": while Broderip nobly owns up to his black heritage, "Margaret's decision leaves her thereafter in complete isolation" (135). While Davis's novel does not wholly reward either character, it presents Broderip as finally noble if "impure," while it consigns Margaret to a haughty, "stony" silence.

Sculptural metaphors have governed the repeated making and breaking of families, and the ambivalent debate over nature and nurture, for both strains of Davis's story line. Garrick Randolph molds the illegitimate and impoverished Ross into his statuesque ideal, but then takes umbrage when she disrespects his mother's picture and the Southern ideals she already represents. John Broderip sees Margaret as statuesque in her perfection, but finds she cannot love someone who does not match her purity. Davis introduces further complications, as Randolph sells an old slave "down the river" to secure the endangered family will, and as Broderip fights in an African American regiment in the Civil War. But the closing scenes and the surgeon's change of heart do not resolve the novel's larger questions, and in the end it is difficult to say who triumphs and who suffers in a novel forever vexed in terms of nature and nurture. Davis's characters who harbor secrets about black heritages or impoverished childhoods experience these secrets as black drops or spots on their "souls," which still can seem ennobled. But those who are free of such spots take pains to stay unblemished, which still can seem bitter and crass. Davis's women stoically accept society's judgment on "tainted" individual character, while her men desperately cut at the bodies that betray the taint to others. Lisa A. Long rightly concludes that the narratives of Davis and Elizabeth Stewart Phelps "are audience-oriented primarily in that they encourage self-examination of the fragmented, alienated self" ("Postbellum" 268), though not all readers would accept the invitation. Davis roused those who were willing to come into contact with people less "pure" than themselves, but also realized that others would not wish to extend their sympathy, so much as preserve their purity. Some would want to experience the "mud and foul effluvia" that shaped figures like Hugh, while others would see themselves neither shaped nor "fragmented" by the unfortunate condi- 
tions of working-class lives.

At one point in her collection of memoirs, Bits of Gossip, Davis revisits these motifs as she enumerates the long-term effects of the Civil War from the perspective of the turn of the century. She suggests that the conflict had produced America's first class of millionaires and the material excesses of trusts and robber barons. But "a more wholesome effect of the long quarrel," the Civil War, was that it "made of us a homogeneous people, which we had never been before. The Pennsylvania Dutchman and the Californian learned to know each other as they sat over the camp-fire at night, and when the war was over they knew the Southerner better and liked him more than they had done before they set out to kill him" (Writing Cultural Autobiography 86). Davis refers to widespread white populations communing in unprecedented ways, and makes soldiers' fireside conversations stand in for Reconstruction's protracted sectional reconciliations. She retrospectively constructs the Civil War not as a struggle to preserve some kind of pure national stock, but as a great conjoining of previously distinct regions and ethnicities. More privileged Americans had involved themselves in foreign environments like Wheeling's "mud and foul effluvia," and fewer had kept themselves "pure," like the heroines of Waiting for the Verdict who consign themselves to the lonely, sterile drawing rooms of patrician Anglo-Americans.

Davis's fiction joins that of other women in recounting this gradually diminishing power of regional and demographic borders to distinguish between groups and determine individual identities. Harriet Beecher Stowe had written the phenomenally successful Uncle Tom's Cabin ( 1852 ), only to find that if she could be voluminous in print, she necessarily had to be more silent in public than her husband, theologian Calvin Stowe. Supposed nervous illness and its treatment shaped the creative lives and identities of women in later decades, giving rise to characters such as the heroine of Charlotte Perkins Gilman's "The Yellow Wallpaper" (1892). By the end of the century, Kate Chopin's Edna Pontellier moved from a realm in which reception parlors constrained her freedom and unusual conduct "tainted" her reputation, to a new house that seemed perpetually under construction, to seductive, limitless seas that held little power to shape or restrain her. These characters of American realism cope with the forces that impose identities 
upon individual personalities, as they try to overcome them; these authors of American realism fictionalize the impositions of real lives in the histories of their characters, as they explore the limits of their readers' sympathies. They prompt reluctant readers to see that the cruelly shaped lives of fictional characters, even those of other races and classes, correspond to the fragmented existence of people like themselves. They ask, that is, that readers look past borders of gender, race, and class, and find themselves glimpsing someone shaped like Hugh.

University of California-Davis

\section{NOTES}

I. Book-length works on Davis that have followed Tillie Olsen's republication of the novel include Pfaelzer, Harris, and Rose. Thomson, Seltzer, Dimock Lasseter, Long's "The Postbellum Reform Writings," Nelson, and Schocket contribute to scholarship on her work while extending beyond her canon.

2. This article addresses Life in the Iron-Mills and Waiting for the Verdict in an effort to foreground Davis's sculptural motifs. The artist-character who struggles with frustrated efforts of self-formation, and the dual processes of internal and external shaping, resonate as well in Margret Howth, "Paul Blecker," "Blind Tom," and "The Wife's Story," among other works by Davis.

3. A letter Davis wrote to James Fields indicate that he had thought the initial drafts of Margret Howth "assembled the gloom" too depressingly for the magazine's readers (qtd in Yellin 212). Pfaelzer, Harris, Yellin, and more recently, Long read the history of this novel's revision as a case of a male editor insisting that a woman's work appear more conventionally "feminine." Yellin reconstructs the novel's form prior to Fields's editing, and Long argues that Davis's narrative plot subverts the authority of Fields's editorial pen ("Imprisoned"). While my own work is less interested in a textual history of Margret Howth, I build upon this understanding of a writer complying with a predominantly male publishing establishment.

4. Readers have reached different conclusions here, often seeing gender categories as vexed but distinct. While some have read Hugh as one component of a "divided female subject," or as a male artist-character attempting "a colonization of the female form" (Pfaelzer 36; Schreiber I07), this seems on the other hand to be one instance of Davis "showing that the 'natural' behaviors ascribed to men and women are not natural at all," and thereby demonstrating that "gender emerges as one of a number of nebulous terms used by nineteenth-century Americans to construct their identities" (Long, "Postbellum" 266).

5. Many readers discuss the narrator as a woman without providing a basis for 
this assumption. Hood has identified "her" as Deb, who has returned thirty years later to tell the tale. Schocket notes in passing how the narrator "is never given a name or a gender" ("Discovering" 49), and follows suit in his commentary, as I have tried to do in mine. Recall as well that The Atlantic Monthly originally published Davis's story without a byline. If the magazine did not designate the story as the work of a man or a woman, a Northerner or a Southerner, then Davis's efforts to obscure the identity of the speaker is consistent with the conditions of publication imposed by the periodical.

6. Pfaelzer notes that Broderip's heritage is particularly obscure and atypical for many who fit the tragic mulatto stereotype. The African American slave Hugh turns out to be Broderip's father, and thus Broderip's "story does not include the rape of a slave mother, the origin of most racially mixed slaves" (Pfaelzer I46). Indeed, Davis never precisely identifies the source of his Caucasian identity or the basis for his claim to inherited "purity."

\section{WORKS CITED}

Davis, Rebecca Harding. Life in the Iron-Mills. I 86r. Ed. Cecelia Tichi. Bedford Cultural Editions. Boston: Bedford Books, I 998.

- Margret Howth: A Story of Today. I862. Upper Saddle River, NJ: Gregg Press, I970.

"Paul Blecker." The Atlantic Monthly I 1, 67 (May, I863): 580-98; I I.68 (June, I 863): 677-9 I; I 2.69 (July, I 863): 52-69.

. Bits of Gossip. Boston: Houghton Mifflin, r904. Rpt. Rebecca Harding Davis: Writing Cultural Autobiography. Ed. Sharon M. Harris and Janice Milner Lasseter. Nashville: Vanderbilt University Press, 200 I.

Waiting for the Verdict. I867. Upper Saddle River, New Jersey: Gregg Press, 1968.

Dimock, Wai Chee. "Class, Gender, and a History of Metonymy." Rethinking Class: Literary Studies and Social Formations. Ed. Wai Chee Dimock and Michael T. Gilmore. New York: Columbia University Press, 1994. 57-104.

Harris, Sharon M. Rebecca Harding Davis and American Social Realism. Philadelphia: University of Pennsylvania Press, I99i.

Hood, Richard A. "Framing A Life in the Iron-Mills." Studies in American Fiction 23. I (I995): 73-84.

Lasseter, Janice Milner. "Hawthorne's Legacy to Rebecca Harding Davis." Hawthorne and Women: Engendering and Expanding the Hawthome Tradition. Ed. John L. Idol and Melinda M. Ponder. Amherst: University of Massachusetts Press, I999. I68-78. 
Long, Lisa A. "Imprisoned In / At Home: Criminal Culture in Rebecca Harding Davis's Margret Howth: A Story of Today." Arizona Quarterly 54.2 ( I998): $65-98$.

"The Postbellum Reform Writings of Rebecca Harding Davis and Elizabeth Stewart Phelps." The Cambridge Companion to Nineteenth-Century American Women's Writing. Ed. Dale M Bauer and Philip Gould. London: Cambridge University Press, 2001. 262-83.

Nelson, Dana D. "Representative/Democracy: The Political Work of Countersymbolic Representation." Materializing Democracy: Toward a Revitalized Cultural Politics. Ed. Russ Castronovo and Dana D. Nelson. Durham: Duke University Press, 2002. 218-47.

Olsen, Tillie. "A Biographical Interpretation." Life in the Iron Mills. Ed. Tillie Olson. New York: Feminist Press, 1972.

Pfaelzer, Jean. Parlor Radical: Rebecca Harding Davis and the Origins of American Social Realism. Pittsburgh: University of Pittsburgh Press, I996.

Schocket, Eric. "'Discovering Some New Race': Rebecca Harding Davis's Life in the Iron Mills and the Literary Emergence of Working-Class Whiteness." PMLA I 5 (2000): 46-74.

- 'Undercover Explorations of the 'Other Half', Or the Writer as Class Transvestite." Representations 64 (I998): 109-33.

Scheiber, Andrew J. "An Unknown Infrastructure: Gender, Production, and Aesthetic Exchange in Rebecca Harding Davis's 'Life in the Iron Mills." Legacy I I.2 (1994): IOI-I 7 .

Seltzer, Mark. Bodies and Machines. New York: Routledge, 1992.

Thomson, Rosemarie Garland. "Benevolent Maternalism and Physically Disabled Figures: Dilemmas of Female Embodiment in Stowe, Davis, and Phelps." American Literature 68.3 (1996): 555-86.

Yellin, Jean Fagan. "The 'Feminization' of Rebecca Harding Davis.” American Literary History 2 (1990): 203-19. 